\title{
Usefulness of Microsatellites for Positioning the Tunisian Almond germplasm in its Mediterranean Geographic Context
}

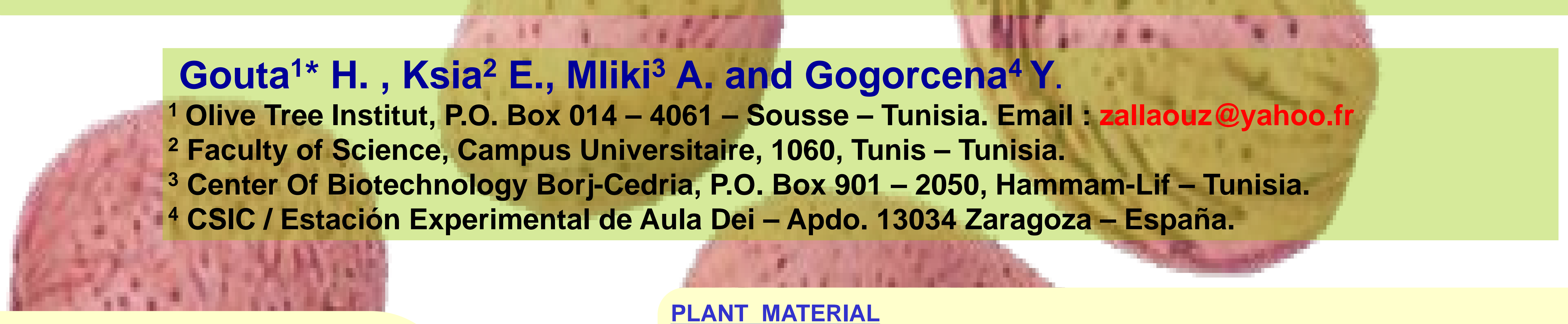

\section{INTRODUCTION}

Microsatellites or SSRs are currently being employed for molecular characterization, estimation of genetic diversity and genetic relationships among almond cultivars and related Prunus species. As little information is available about the genetic diversity and relatedness within Tunisian almond cultivars and their relationship with the others originated from other countries, the aims of this work are to identify by SSR analysis the cultivars preserved in the Tunisian National Collection and the landraces collected directly from different sites of the country (Sidi Bouzid and Bizerte), to determine their relatedness to European and American cultivars and to estimate the level of genetic diversity.

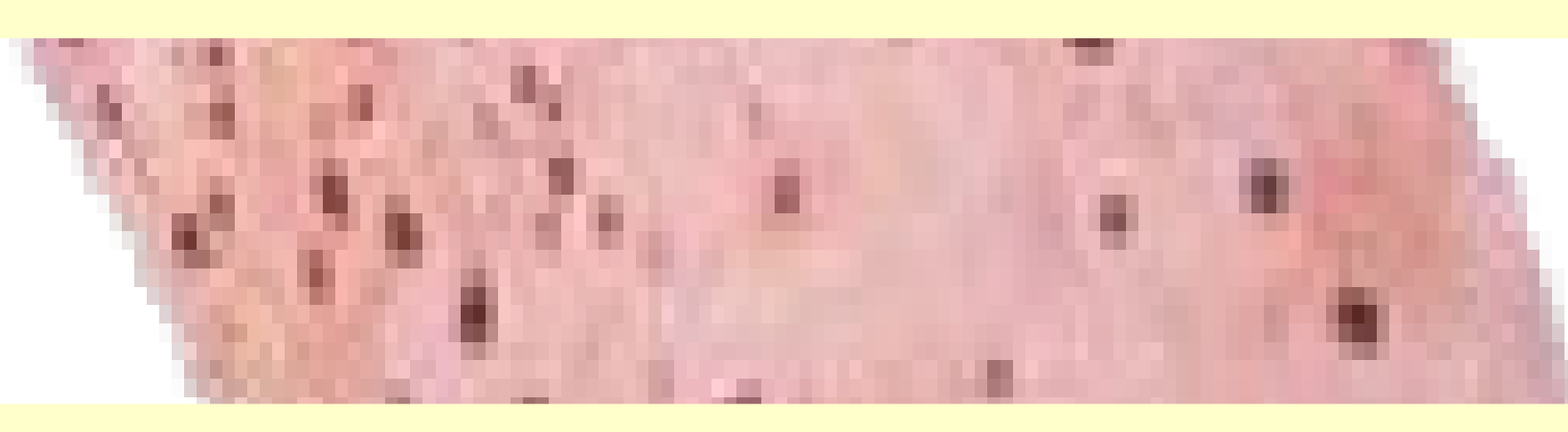

\section{RESULTS}

The majority of the Tunisian genotypes were clustered together but they showed several minor groups, which revealed their high heterogeneity (cluster A, Fig. 2). This is probably due to the traditional method of propagation of this species all over the country which was mainly done by seeds (openpollinated), until the more extensively use of grafting in the Mediterranean at the beginning of the 20th century (Grasselly and Crossa Raynaud 1980). In addition, the need of out-crossing of this species as self incompatible is assumed to be one of the main causes of the existing genetic diversity.

The clear distinction between the majority of local cultivars from the central and Southern part and all of the other groups which was not previously demonstrated using RAPD (Gouta et al. 2008) is a proof of the higher discrimination power of SSRs compared to RAPD.

In contrast to what has been observed in group $A$ (Fig. 2), the local cultivars from Bizerte (north of Tunisia), were clustered in the group $C$ with some European and all the North American cultivars. These last originated from material of the Languedoc region of France (Kester 1994). In fact, the position of this area in the extreme north of Tunisia probably favored the exchange of genotypes between both shores of the Mediterranean Sea (Fig.3). The presence in group C of the two cultivars: 'Porto Farina' as was the old name of Ghar El Melh (a city in Bizerte) and 'Faggoussi' could be another fact in favor of this hypothesis. Moreover, the high bootstrap values observed in the sub cluster grouping cultivars from Bizerte $(85 \%$ for 'Abiodh Ras Djebel' and 'Khoukhi' and 93\% for 'Dillou' and 'Blanco') support the specificity of this site.

\section{REFERENCES}

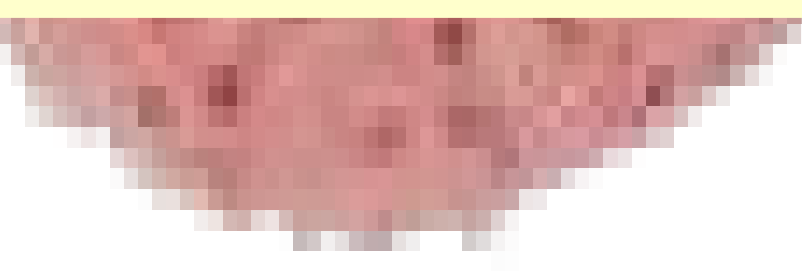

82 almond genotypes most of them originated from Tunisia (50), the others included in the Nationa collection were from France (9), Italy (7), Morocco (1), Spain (8), USA (3), or were of unknown origin (4). Leaves were sampled in early Summer and were immediately ground to a powder in liquid nitrogen before storage at $-80^{\circ} \mathrm{C}$

METHODS

DNA extraction: Total DNA was extracted from young and healthy leaf tissue following the protocol of Doyle \& Doyle (1987).

DNA amplification: DNA was amplified by PCR using ten primer pairs of microsatellite nine pairs derived from a library enriched for AG/TC motifs, constructed with the almond cultivar 'Texas' (Mnejja et al. 2005) and one pair previously cited by Joobeur et al. (2000).

Data analysis: Data were analyzed as discrete variables (1) for the presence and (0) for the absence of a similar band (Fig.1) Cluster analysis was done using SAHN procedure of NTSYS software ver. 2.1 (Rohlf 2000), which uses the unweighted pair group method with arithmetic averages (UPGMA) to cluster the genotypes. Obtained results were used to construct a final dendrogram showing all accessions. Bootstrap support values were obtained from 2000 replicates using TREECON 1.3b (Van de Peer and De Wachter 1994).
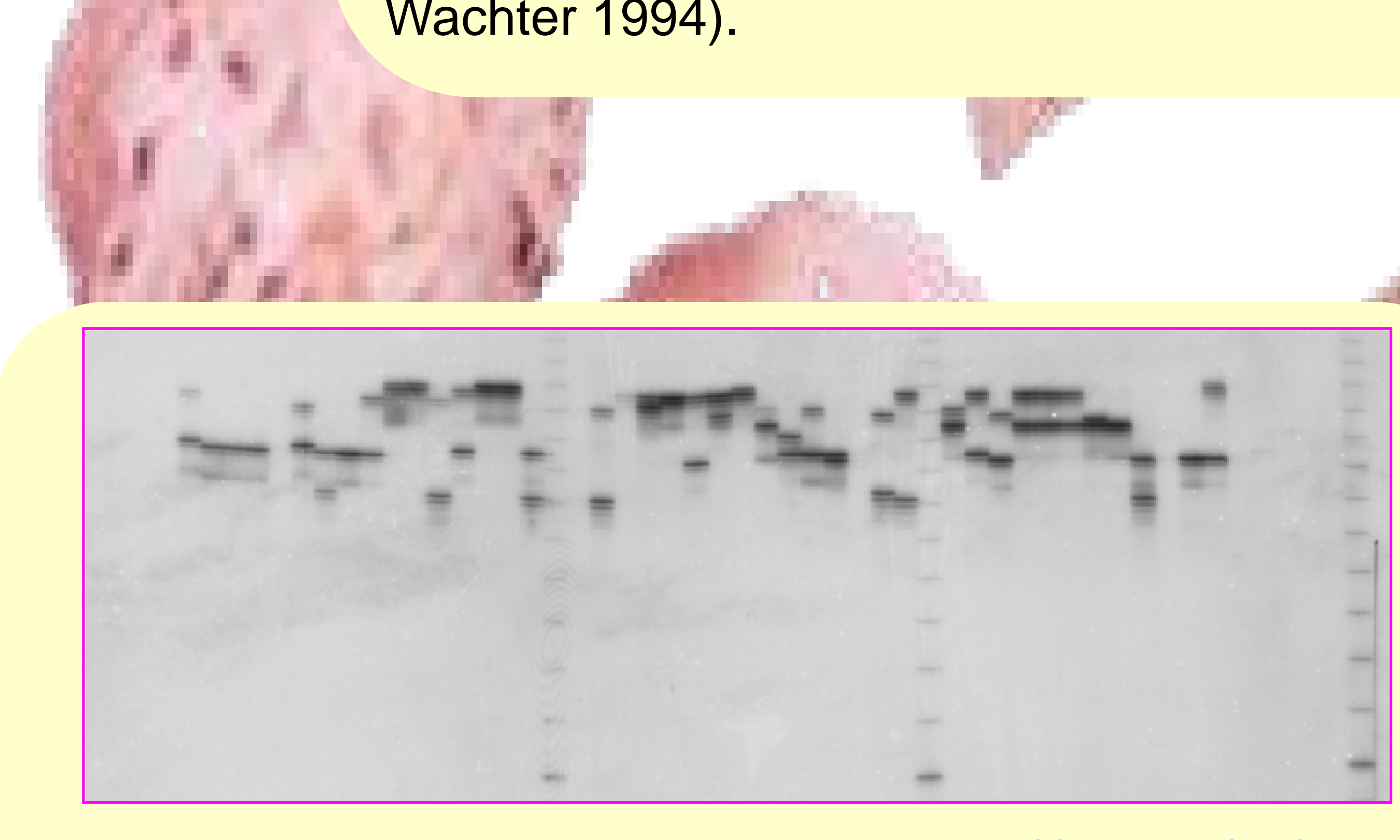
on a part of the 82 almond genotypes
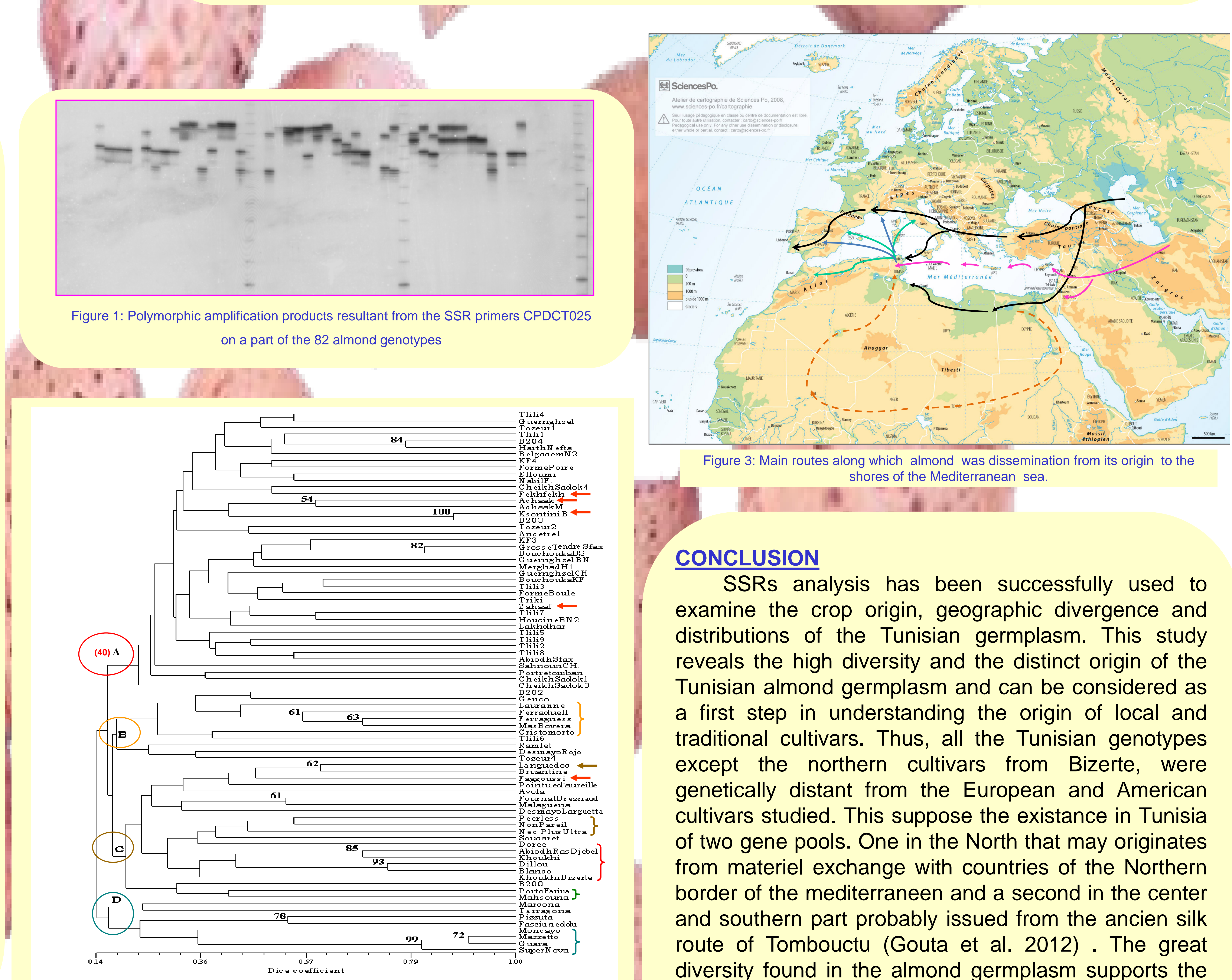

\section{CONCLUSION}

SSRs analysis has been successfully used to examine the crop origin, geographic divergence and distributions of the Tunisian germplasm. This study reveals the high diversity and the distinct origin of the Tunisian almond germplasm and can be considered as a first step in understanding the origin of local and traditional cultivars. Thus, all the Tunisian genotypes except the northern cultivars from Bizerte, were genetically distant from the European and American cultivars studied. This suppose the existance in Tunisia of two gene pools. One in the North that may originates from materiel exchange with countries of the Northern border of the mediterraneen and a second in the center and southern part probably issued from the ancien silk route of Tombouctu (Gouta et al. 2012). The great diversity found in the almond germplasm supports the idea that Tunisia has a valuable source of almond genes to be exploited in further international breeding programs. 
Monday 27
16:00-19:00 Registration and placement of posters.

Tuesday 28

08:00-10:00

09:00-09:30

09:30-10:00

Registration and placement of posters.

Opening Ceremony.

Opening lecture. Influence of research on modernization of almond and pistachio culture in Mediterranean area during the last forty years and some challenges for the future.

Vargas FJ.

Session 1. Breeding and Genetics

S1. Plenary lecture. Tree crop genetics and breeding: Not seeing the orchard for the

10:00-10:30 leaves.

Gradziel TM.

10:30-10:45 S1-1. Genetic mapping in pistachio by simple sequence repeat markers.

Akyüz A, Guney M, Khodaei M, Kafkas S.

10:45-11:00 S1-2. Breeding extra-late flowering self-compatible cultivars at CEBAS-CSIC in Murcia, Spain.

Dicenta F, Egea J, Ortega E, Martínez-Gómez P, Sánchez-Pérez R, Rubio M, Martínez-García P, Gómez EM, del Cueto J.

11:00-11:30 Coffee break and posters session.

11:30-11:45 S1-3. Vigour and leafing characteristics of almond offspring in Turkey. Acar I, Yilmaz A, Arpaci S.

11:45-12:00 S1-4. Genetic variation and frequency of $S$-alleles in Iranian almond cultivars. Mousavi A, Fatahi R, Zamani Z, Imani A, Dicenta F, Ortega E.

\section{Session 2. Biology and Physiology}

S2. Plenary lecture. Bitterness in almond.

$12: 00-12: 30$ Sánchez-Pérez R.

$12: 30-12: 45$

S2-1. Improving fruit set in self-fertile almond cultivars with bumblebees. Miarnau X, Rovira M, Batlle I, Alegre S, Vargas FJ.

$12: 45-13: 00$

13:00-13-30

$13: 30-16: 00$

16:00-16:15

$16: 15-16: 30$

$16: 30-16: 45$

$16: 45-17: 00$

S2-2. Influence of pollinizer arrangement, bloom timing and almond cultivar ratios on orchard productivity and crop value.

Connell JH, Floyd J, Limberg J, Miller B, Boles J.

\section{Poster session}

Lunch time.

S2-3. Identification and characterization of prunasin hydrolases in sweet and bitter almonds and their expression in tobacco plants.

del Cueto J, Dicenta F, Sánchez-Pérez R.

S2-4. Characterization of the region between S-RNase and SFB genes in almond genotypes with the same $S f$-haplotype but different incompatibility phenotypes. Gómez EM, Dicenta F, Ortega E.

S2-5. Influence of plant water status on structure of epicormic and proleptic shoots of almond trees.

Negrón C, Contador ML, Lampinen BD, Metcalf SG, Guédon Y, Costes E, DeJong TM. S2-6. Almond self-incompatibility genetics: recent progress and future prospects. Ortega E, Gómez EM, Dicenta F. 
17:30-17:45 S2-7. Yield potential analysis to model dormancy requirements in pistachio. Pope KS, Dose V, Da Silva D, DeJong TM.

17:45-18:00 S2-8. Self and cross-pollination in 'Francolí and 'Guara' almond orchards. Martín I, Rovira M.

18:00-18:15 S2-9. Self-compatibility expression in almond by pollen tube growth. Socias i Company R, Kodad O, Fernández i Martí A, Alonso JM.

18:15-18:30 S2-10. Chilling and heat requirements for flowering of the main pistachio cultivar Mateur in the growing area of Tunisia.

Salhi H, Ben Mimoun M, Ghrab M.

Wednesday 29

Session 3. Plant Protection

09:00-09:30

S3. Plenary lecture. Pests problems in pistachio producing areas of world and means of control.

Mehrnejad MR.

09:30-09:45 S3-1. Alternaria blight infections of pistachio fruits in the southeastern Anatolia region of Turkey.

Can C, Konukoglu F, Ozgun E, Kusek M, Ozkilinc H, Aktan A, Citak M, Sarpkaya K.

09:45-10:00 S3-2. Late-season chemical control of Pacific Spider Mite (Tetranychus pacificus) in California almonds.

Haviland DR, Rill SM, Higbee BS.

10:00-10:15 S3-3. Synthesis and activity of terpenes in leaves and galls of Pistacia spp: Manipulation of plant volatile production by insects for their own defence. Inbar M.

10:15-10:30 S3-4. Growers can reduce sprays during control of Botryosphaeria panicle and shoot blight of pistachio by using a leaf wetness model.

Michailides TJ, Morgan DP, Puckett RD.

10:30-10:45 S3-5. Controlling the first generation of Navel Orangeworm in almonds. Zalom FG, Nicola NL.

10:45-11:15 Coffee break and poster session.

\section{Session 4. Fruit Technology}

S4. Plenary lecture. Almond quality requirements for industrial purposes. Its

11:15-11:45 relevance for the future acceptance of new cultivars from breeding programs. Romero A.

11:45-12:00 S4-1. Effects of drought stress on almond fatty acids and tocopherols. Zhu Y, Taylor C, Sommer K, Wilkinson K, Wirthensohn M.

12:00-12:15 S4-2. Mineral compound, fat and fatty acid compositions of Turkish pistachio cultivars.

Çınar B, Okay Y.

12:15-12:30 S4-3. Physical and chemical traits of almond kernels of the local almond populations in Morocco: commercial and industrial end-uses.

Kodad O, Estopañán G, Fagroud M, Juan T, Socias i Company R.

12:30-12:45 S4-4. Pomological and biochemical characterization of two Turkish almond cultivars grown in the Anatolia region.

Oguz HI, Font i Forcada C, Giménez R, Gogorcena Y, Yılmaz A, Betrán JA, Moreno MA.

$12: 45-13: 30$

Posters session.

$13: 30-16: 00$ Lunch time. 
S5. Plenary lecture. Plant genetic resources of Pistacia spp. and pistachio cultivars

$16: 00-16: 30$ in the world.

Ak BE.

16:30-16:45 S5-1. Performance of six almond rootstocks with long-term exposure to sodium and chloride.

Doll D, Duncan R, Hendricks L, Micke W.

16:45-17:00 S5-2. Comparisons of flowering and harvest dates, yield and nut quality parameters of 'Golden Hills' and 'Lost Hills' pistachio cultivars to 'Kerman'.

Kallsen CE, Parfitt DE, Holtz BA.

17:00-17:15 S5-3. Nursery performance of GN22 and GF677 almond rootstocks.

Atli HS, llikcioglu E, Sarpkaya K.

17:15-17:30 S5-4. Identification and registration of Iran commercial pistachio by some morphological characteristics.

Javanshah A, Tajabadipour A, Shuraki YD, Sherafati A, Mortazavi A, Kashanizadeh S, Esmaeilpour A.

17:30-18:00 Coffee break and posters session.

18:00-20:00 GREMPA meeting.

Thursday 30

Session 6. Orchard Management

09:00-09:30 S6. Plenary lecture. Pistachio Orchard Management.

Ferguson L.

09:30-09:45 S6-1. Development and long-term salt tolerance of pistachios from planting to maturity using saline groundwater.

Sanden BL, Ferguson L, Corwin DL.

09:45-10:00 S6-2. Developing allometric equations for estimating biomass of orchard-grown Pistacia vera L. in California.

Aguaron Fuente E, Roberts B.

10:00-10:15 S6-3. The effect of almond tree planting density on tree size, yield and profitability. Duncan RA, Lampinen BD.

10:15-10:30 S6-4. High density planting in almond orchards. Miarnau X, Montserrat R, Batlle I, Alegre S, Vargas FJ.

10:30-10:45 S6-5. Super high density almond orchards. Rius X, Bordas M, Torrents J.

10:45-11:15 Coffee break and poster session.

11:15-11:30 S6-6. Assessing almond orchard water use: evaluation of methods. Espadafor M, Lorite I, Orgaz F, Testi L, Fereres E.

11:30-11:45 S6-7. Orchard carbon and nutrient recycling. Holtz BA, Doll D, Browne G.

11:45-12:00 S6-8. Life cycle assessment of long-lived perennial cropping systems: biomass-based energy production and greenhouse gas footprints in California almond and pistachio production.

Marvinney E, Kendall A, Brodt S, Dejong T, Roberts B.

12:00-12:15 S6-9. A preliminary report on mechanical pruning utilising a '1-side mechanical slant topping' technique on pistachio trees.

Zhang J.

12:15-12:30 S6-10. Influence of potassium nitrate, gibberellin and benzyl adenine on bud break, fruit set and branch induction of almond trees.

Elsabag AS.

12:30-13:30

Posters session.

13:30-16:00 Lunch time. 
S7. Plenary lecture. Economy and markets of almond.

16:00-16:30

$16: 30-16: 45$

$16: 45-17: 00$

$17: 00-17: 15$

$17: 15-17: 45$

$17: 45-18: 30$

18:30-19:00

21:30 Joyce Ch, Skinner R.

S7-1. Membership within the Nonpareil marketing group: Examination of an unclassified accession.

Ledbetter CA, Sisterson MS.

S7-2. The Italian almond industry: new perspectives and ancient tradition. Sottile F, Barone E, Palasciano M.

S7-3. Proposing extension programs for Iranian pistachio industry. Daneshvar V, Taqizade Z.

Coffee break and posters session.

ISHS meeting.

Closing session.

Symposium dinner.

Friday 31

08:30-19:00 Technical and cultural visit. 
P1-1. Mapping QTLs for nut and kernel traits in almond.

Fernández i Martí A, Font i Forcada C, Socias i Company F.

P1-2. Identification of simple sequence repeat (SSR) markers linked to flowering time in almond by modified bulked segregant analysis.

Rasouli M, Fatahi R, Zamani Z, Imani A, Martínez-Gómez P.

P1-3. New strategies of early selection for flowering time in almond.

Rubio M, Dicenta F.

P1-4. Random amplified microsatellite polymorphism (RAMP) application in Prunus characterization and mapping.

Salazar JA, Rasouli M, Martínez-Gómez P.

P1-5. Usefulness of microsatellites for positioning the Tunisian almond germplasm in its Mediterranean geographic context.

Gouta H, Ksia E, Mliki A, Gogorcena Y.

Session 2. Biology and Physiology

P2-1. The effects of different $\mathrm{NaCl}$ applications on the growth of almond grown in Batman, Turkey.

Akbaş F, Işıkalan Ç, Kuru is, Karakuş P.

P2-2. Self-incompatibility in almond: How does it work?

Gómez EM, Dicenta F, Ortega E.

P2-3. Developing a Growing Season Phenology Model for Pistachio Cultivars.

Allan C, Ferguson L.

P2-4. In vitro and in vivo models to study graft union development in pistachio.

Andreu P, Imbroda-Solano I, García E, Jurado Valle JI, Lorente P, Arbeloa A, Padilla IMG, Marín JA, Barceló.Muñoz A.

P2-5. Critical factors limiting pistachio micropropagation.

Arbeloa A, García E, Lorente P, Andreu P, Marín JA.

P2-6. Study of some factors affecting Pistacia terebinthus $\mathrm{L}$. seed germination.

Imbroda-Solano I, González.Padrón MY, Padilla IMG, Barceló-Muñoz A.

P2-7. In vitro culture of Pistacia vera: Factors affecting shoot tip necrosis.

García E, Lorente P, Marín JA, Andreu P, Arbeloa A.

P2-8. Selection and propagation of Pistacia terebinthus L.

Gonzalez-Padrón MY, Imbroda-Solano I, Padilla IMG, Barceló-Muñoz A.

P2-9. Description of expressed proteins associated to the self-incompatible and selfcompatible response in almond [Prunus dulcis (Miller) D.A. Webb].

Martínez-García PJ, Dicenta F, Ortega E.

P2-10. The effect of saline and different growth conditions on seed germination of almond grown in Batman, Turkey.

Işıkalan Ç, Akbaş F, Karakuş P, Kuru is.

P2-11. Effects of increasing root zone $\mathrm{Ca} 2+$ on $\mathrm{Na}+$ uptake, transport and plant growth and physiology in Pistachio grown in saline soils.

Mortaz M, Sanden B, Brown P, Ferguson L.

P2-12. Micropropagation of Pistacia khinjuk juvenile shoots using temporary immersion bioreactor system (TIS).

Tilkat E, Süzerer V, Ersali Y, Hoşer A, Gül C, Kiliç MF, Ayaz Tilkat E, Akdemir H, Özden Çiftçi $Y$, Onay A.

P2-13. Almond flower tolerance to spring frosts in new Spanish cultivars.

Miarnau X, Batlle I, Alegre S, Vargas FJ.

P2-14. Water use efficiency and leaf water relations in breeding lines of almond.

Rahimi Eichi V, Tyerman S, Downey M, Wirthensohn M.

P2-15. Improved shoot multiplication of lentisk (Pistacia lentiscus L.) in vitro using

different carbohydrates and medium strengths.

Kilinc FM, Suzerer V, Ozden Ciftci Y, Koc Y, Akdemir H, Yildirim H, Tilkat E, Onay A. 
P3-1. The unique and evolving pest complex in northern Chihuahuan desert pistachio orchards.

Heerema R, Sutherland C, Gordon E.

P3-2. The psyllids of pistachio trees in Iran.

Mehrnejad MR

P3-3. The effect of kaolin to control Septoria Leaf Spot disease in pistachio in Turkey.

Sarpkaya K, Yilmaz A.

P3-4. Resistance to Capnodis tenebrionis in Prunus rootstocks.

Soler A, Torrents J, Dicenta F.

P3-5. Cycle of Chaetoptelius vestitus on pistachio fruit in Algeria.

Méziou-Chebouti N, Chebouti Y, Merabet A, Bissaad FZ, Behidj N, Doumandji S.

P3-6. Evaluation of susceptibility of Pistacia genotypes to Verticillium wilt disease.

Triki MA, Chelli Chaabouni A, Rhouma A, Cheffi M, Boudaya M.

Session 4. Fruit Technology

P4-1. Determination of chemical traits of some foreign almond cultivars grown in Sanliurfa province.

Ak BE, Parlakçi $\mathrm{H}$, Turkoglu $\mathrm{H}$.

P4-2. Influence of temperature on the production quality parameters in pistachio (P. vera L.).

Gijón MC, Memmi H, Pérez-López D, Couceiro JF, Moriana A, Martínez E, Guerrero J.

P4-3. Real time PCR to detect almond allergen coding sequences in processed foods.

Prieto N, Iniesto E, Burbano C, Rodríguez J, Rovira M, Crespo JF, Cuadrado C, Linacero R.

P4-4. Varietal traceability in almond products by SSR (Simple Sequence Repeat) markers.

Sánchez-Pérez R, Dicenta F, Martínez-Gómez P.

P4-5. Oil and crude protein content of almond genotypes selected in Serbia and cultivars Troito, Texas and Marcona.

Čolić S, Zec G, Janković Z, Rahović D, Bakić I.

Session 5. Cultivars Behaviour

P5-1. Myrotop ${ }^{\circledR}$, a new almond rootstock tolerant to waterlogging, to Armillaria Root Rot and resistant to Root-Knot nematodes.

Duval $\mathrm{H}$, Masse M.

P5-2. Methods for characterizing salinity response in pistachio rootstocks. Godfrey J, Ferguson L, Zwieniecki M, Drakaki G.

P5-3. Phenological behavior of two new male cultivars of pistachio (Pistacia vera L.): 'Chaparrillo' and 'Guerrero'.

Guerrero J, Memmi H, Pérez-López D, Couceiro JF, Moriana A, Martínez E, Gijón MC.

P5-4. Almond germplasm in Bostanlyk area (Uzbekistan): preservation and exploitation.

Sottile F, Tsoy M, Abdurasulov A, Peano C.

P5-5. Morphological and micro-morphological leaf features of three Pistacia species

$(P$. lentiscus, $P$. terebinthus and $P$. saportae) from different wild populations.

Belhadj S, Doghbage A, Mevy JP, Gauquelin T.

P5-6. Assessment of some reproductive traits of male pistachio genotypes in Tunisia.

Chelli Chaabouni A, Ghrab M, Ben Slimane G, Chatti H, Njeh A, Ben Mimoun M. 
P5-7. Comparison of growing of pistachio rootstocks on different planting intervals. Arpaci S, Acar I, Karadag S, Atli HS, Ak BE, Sarpkaya K.

P5-8. Differences in drought tolerance in almond cultivars grown in Apulia region (Southeast Italy).

Palasciano M, Logoluso V, Lipari E.

P5-9. Comparing three Iranian pistachio (Pistacia vera L.) rootstocks regarding drought tolerance.

Roozban MR, Arzani K.

\section{Session 6. Orchard Management}

P6-1. Almond growing in Andalucía (Spain). Introduction and adaptation of new varieties.

Arquero O, Serrano N, Romacho FJ.

P6-2. Almond plantations in bare-degraded forest and treasure lands: achievements and failures.

Erdogan V.

P6-3. Organic wastes as alternative to inorganic fertilizers in crop cultivation. Hernández T, Chocano C, Moreno JL, García C.

P6-4. Efficiency of California trunk shaking pistachio harvesters. Ferguson L, Miles JA, Castro García S, Glozer K.

P6-5. Characterization of pistachio fruit growth stages as a base for irrigation scheduling.

Memmi H, Gijón MC, Guerrero J, Couceiro JF, Pérez-López D.

P6-6. Effect of some biostimulants on physiological and reproductive characteristics of Iranian almond cultivar Mamaei.

Babadaei Samani R, Mousavi A, Sadeghi Ghotbabadi F, Zadehbagheri M.

P6-7. Effects of disbudding treatments on seasonal dynamics of macronutrients in fruiting and non-fruiting branches of pistachio trees cultivar Mateur.

Elloumi O, Ghrab M, Ben Mimoun M.

P6-8. Effects of kaolin particle film on some physiological aspects of Pistacia vera cultivar Badami.

Davarynejad Gh, Vatandoost Jartoodeh S, Tehranifar A, Kaveh H, Nourzadeh M. P6-9. Effects of different regulated and sustained deficit irrigation strategies in almond production.

Mañas F, López-Fuster P, López-Urrea R.

P6-10. Rainfed orchards extension program in Iran.

Yadollahi A, Jahansouz MR, Looni A. 